\title{
Anthropology and ecology of the world's savannas
}

\section{Peter D. Moore}

Human Ecology in Savanna Environments. Edited by David R. Harris. Pp.522. (Academic: 1980.) £21.50, \$49.50.

THERE is a romantic appeal about certain of the world's biomes which defies scientific explanation. What is there about desert, rain forest and tundra which excites the imagination, and why does the savanna lack the same magic? It was a similar concern which led David Harris to coordinate the Wenner-Gren Foundation conference in 1976 which formed the basis for this book. The general lack of public, and perhaps even scientific, interest in the savanna regions is all the more surprising when one considers the close association of early Man with these tropical grasslands, together with the modern problems of pastoral societies in these regions and the growing conflict with wildlife conservation.

The book is divided into three parts. The first deals with the occupation and exploitation of savanna environments since early prehistoric times. J. Desmond Clark attempts a synthesis of the pollen and vegetation data of Van Zinderen Bakker with the rapidly accumulating information concerning prehistoric communities in Africa. Man, he claims, remained restricted to the open savanna environments until about one million years ago, when Homo erectus first invaded the Ethiopian highlands. Hammond provides a similar synthesis for Central and South America, although the palaeoecological data is very much thinner. Within this section of the book also fall a number of anthropological studies of tropical Australia, Africa, India and South-east Asia. To an ecologist, some of the uses of ecological terms in an anthropological context may seem a little misplaced; is it reasonable, for example, to say that pastoral behaviour in East Africa shows the elements of an r-strategy? The statement is largely based upon the process of local resource exhaustion, followed by a moving on to new grazing land. The MacArthur and Wilson model is becoming unrecognizable.

Overall, one is left with the impression, from this first part of the book, that anthropologists have now gathered much field data from their respective study sites and are searching avidly for generalized models.

In the second part of the book, the emphasis moves from savanna history and exploitation systems, to present ecology and management. Here some authors use the ecosystem approach and one is supplied with data concerning production rates and nutrient distributions, particularly in relation to human land use. Among these papers that of P.A. Jewell, concerning the management of game and domestic livestock in African savanna, is outstanding,

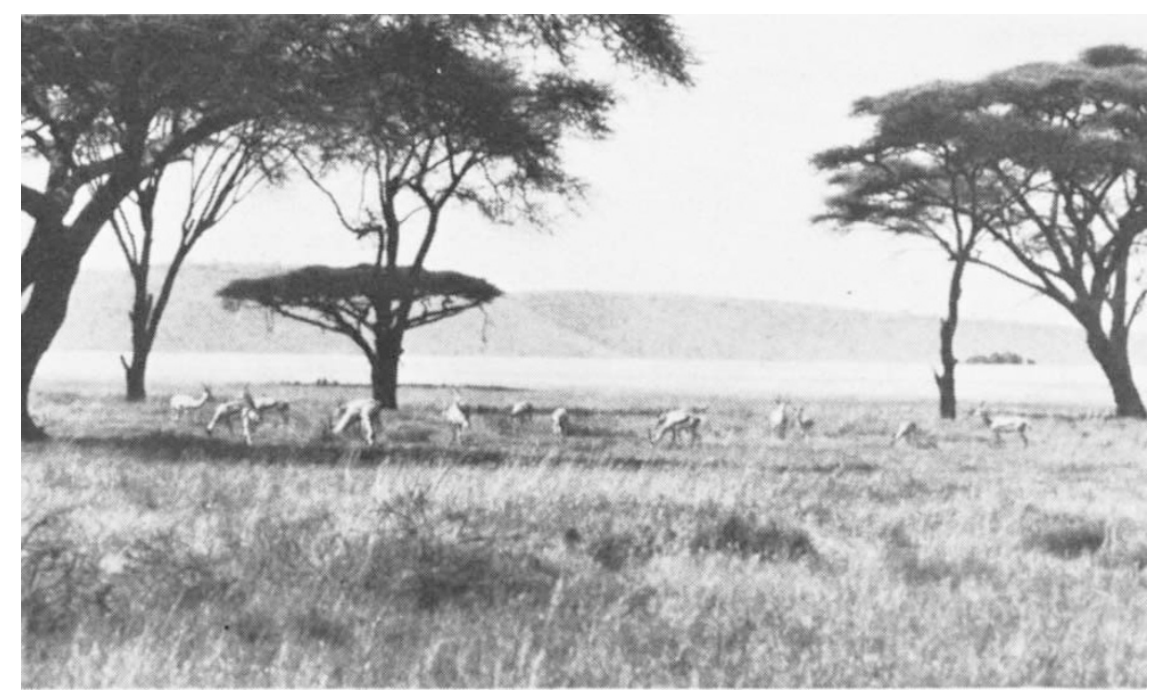

East African savanna: Grant's gazelle grazing in the Serengeti.

both in the clarity of its presentation and in the wealth of carefully chosen data it contains. Beside it, the paucity of information from other areas is apparent.

The final part of the book concerns the human biology of savanna peoples. This contains largely physiological, nutritional and epidemiological information concerning the savanna populations, which is vital for an understanding of the ecology of Man in these areas.

One can always think of other subjects which could have been included to make any book more comprehensive in its coverage. High on my list here would be a

\section{Slime mould jubilee}

\section{G. Turnock}

Growth and Differentiation in Physarum polycephalum. Edited by W. F. Dove and H. P. Rusch. Pp.250. (Princeton University Press: 1980.) $£ 13.70, \$ 25$.

The true slime mould, Physarum polycephalum, has a respected position in the catalogue of lower eukaryotes used for studies of cell biology in general and of differentiation in particular. Two features of its complex life cycle are of especial interest: first, the high degree of synchrony that is characteristic of nuclear division in the coenocytic plasmodium, and, second, the dramatic degree of differentiation involved in the transition from amoebae, which grow and divide as single cells, to plasmodia, which grow without any further cell division. Thus the amoebalplasmodial transition is a link between two vegetative growth phases; it provides a refreshing contrast for the study of differentiation by comparison with contribution by a palaeoecologist, who could put into perspective the limitations of the pollen data, to which so many of the authors refer. Also, a chapter concerning the ecology and importance of fire in savanna would have been helpful. But one must draw the line somewhere, and this book contains more than enough to whet one's appetite and enthusiasm for that neglected biome where Man himself has his roots.

Peter D. Moore is Senior Lecturer in the Department of Plant Sciences, King's College, London. formation of spores or resting stages - not that Physarum cannot supply these as well.

One person, H. P. Rusch, played a particularly important role in stimulating biochemical studies of Physarum, and this book celebrates the silver jubilee of the work begun by his group at the McArdle Laboratory at the University of Wisconsin. Cancer research is the remit of the McArdle Laboratory and Rusch chose Physarum as a model organism for the basic analysis of growth and differentiation, although he admits in the Introduction that his work on carcinogens was becoming hampered by

\section{James Six}

The Construction and Use of a Thermometer by James Six, reviewed in the Autumn Books Supplement of Nature $(288,36 ; 1980)$, is available from Nimbus Books, 84 Sydney Road, London N10 $2 \mathrm{RN}$, price $£ 15+60$ p post and packing. 